\title{
"Amar é ter uma ética afetiva, é ter esse cuidado com o outro": Narrativas sobre amores e lesbianidades
}

"To love is to have an affective ethic, to be careful with others": Narratives about love and lesbianities

"Amar es tener una ética afectiva, es tener cuidado con los demás": narrativas sobre el amor y lesbianidades

Danielly Christina de Souza Mezzari ${ }^{1}$

Resumo da dissertação: A pesquisa teve como objetivo investigar as configurações de relacionamentos amorosos entre mulheres. $\mathrm{O}$ trabalho foi desenvolvido tendo como base os pressupostos tanto da cartografia quanto das produções narrativas (BALASCH, MONTENEGRO, 2003). Esta tem como fundamento a noção de conhecimentos situados, de Haraway, que reconceitua a objetividade ao assegurar a dimensão encarnada e localizada de toda produção de conhecimento. Ao longo da pesquisa entrevistamos cinco mulheres que se relacionavam com mulheres e, junto com cada uma delas, construímos uma narrativa sobre suas histórias. Esta narrativa foi escrita em conjunto com as participantes. Partimos do pressuposto de que para o desenvolvimento de uma pesquisa é preciso haver desejo tanto de quem a propõe quanto de quem participa do processo como um todo. Nesse sentido, não procuramos "dar voz" às participantes, mas criar com elas uma malha coletiva em que fosse

Submetido em: 18/12/2019 - Aceito em: 20/12/2019 - Publicado em: 28/12/2019.

${ }^{1}$ Doutoranda em Psicologia Social pela Universidade Estadual Paulista "Júlio de Mesquita Filho. 
possível em algum nível haver uma experiência de pertencimento. Cada texto evocou uma rede de relações e não simplesmente uma história pessoal ou uma experiência individual. $\mathrm{O}$ trabalho problematizou a invisibilidade das produções teóricas lésbicas mesmo dentro dos feminismos e também o conceito de amor romântico e suas intersecções com marcadores sociais. Procuramos explicitar que o próprio conceito de lesbianidade é fruto de uma produção contemporânea ocidental e se baseia fundamentalmente em concepções binárias. Ainda assim, acreditamos que pode ter uma potência estratégica para marcar experiências da mais diversas. No entanto, não procuramos ao longo da pesquisa definir o que é ser lésbica, mas ao invés disso, tivemos como objetivo potencializar as possibilidades de questionamentos às normas sexuais e de gênero. Com as participantes da pequisa tivemos a oportunidade de vislumbrar produções singulares nas relações com as mais diversas normas sociais. Em alguns momentos foi importante e necessário nas experiências de cada uma delas se assentarem sobre modos de funcionar já bastante consolidados. Ainda assim, também foi possível perceber movimentos de rupturas e questionamentos a mecanismos de repressão e de violências. Elas nos falaram sobre a possibilidade de ver nos rótulos, nas categorizações, um ponto de encontro sem que, no entanto, se transformassem em moradas permanentes. Relataram resistências a tentativas das mais variadas em enquadrar e normalizar seus corpos ainda na infância por meio de gestos, de brincadeiras, e também na vida adulta nas tentativas cotidianas de inserir uma namorada ou companheira na vida familiar. Falaram sobre hostilidades em ambientes de trabalho, sobre a invisibilização que muitas vezes sofrem nesses espaços e sobre como precisam lidar com manifestações hostis de outras pessoas que vão desde o receio com relação a elas até o desprezo e a violência. Foi importante demarcar, também, que todas essas experiências produzem corpos singulares que não se fazem tendo como parâmetro unicamente o gênero e a sexualidade de cada uma destas mulheres. Por fim, pontuamos que trabalhar com as discussões referentes ao campo de gênero e de sexualidade implica quase que inevitavelmente em rever nosso lugar no mundo e nossas relações, rever o modo como aparecemos ou não para outras pessoas e também implica em resistir a processos de opressão e de invisibilização que insistem em nos capturar.

\section{Referências Biliográficas:}


BALASCH, M.; MONTENEGRO, M. Una propuesta metodológica desde la epistemología de los conocimientos situados: las producciones narrativas. Encuentros en psicología social.1(3): 44-48, 2003.

MEZZARI, D. C. S. "Amar é ter uma ética afetiva, é ter esse cuidado com o outro": Narrativas sobre amores e lesbianidades. Dissertação. 2017. 95f. (Mestrado em Psicologia Social) - Universidade Estadual Paulista “Júlio de Mesquita Filho" (UNESP), Assis - SP, 2017. 